\title{
Online testing of Hungarian children's prosocial behavior
}

\section{Anikó Zsolnai \& László Kasik}

To cite this article: Anikó Zsolnai \& László Kasik (2016): Online testing of Hungarian children's prosocial behavior, International Journal of School \& Educational Psychology

To link to this article: http://dx.doi.org/10.1080/21683603.2016.1188032

曲 Published online: 15 Jun 2016.

Submit your article to this journal $\widetilde{ }$

Q View related articles $ک$

View Crossmark data ¿ 


\title{
ARTICLE
}

\section{Online testing of Hungarian children's prosocial behavior}

\author{
Anikó Zsolnai ${ }^{\mathrm{a}, \mathrm{b}}$ and László Kasik ${ }^{\mathrm{a}, \mathrm{b}}$

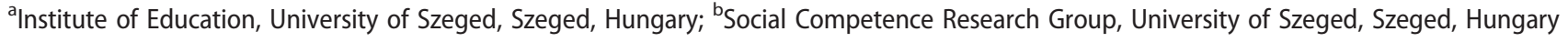

\begin{abstract}
The aim of our cross-sectional investigation was to explore prosocial behavior at the ages of 9, 11, and 13 , and to reveal associations between this social behavior and some background variables such as age, gender, and parents' educational attainment. The participants were 185 Hungarian students and their teachers. Two Likert-type questionnaires (teacher and student versions) were developed and used in this study. These instruments proved to be highly reliable (Cronbach's $\alpha$ : $.79-.87)$. The results from both teachers and students indicate that sharing property and showing a positive attitude toward others are more typical of third-graders (age 9) than of older children. Conversely, standing up for individual interests during teamwork is most typical of the oldest group of children. Students and teachers also agree that third (age 9) and fifth graders (age 13) are more likely to help others than older children. The correlation coefficients for the different factors of prosocial behavior become progressively weaker with age. Cooperation and helping appear to become independent of each other. Our regression analyses reveal that parents' educational level explains equally low shares of the variance in the measured areas of the prosocial behavior for all three age groups.
\end{abstract}

\section{KEYWORDS}

prosocial behavior; schoolage children; online testing
Prosocial behavior is often considered as the basis of human relationships (e.g., Eisenberg, Fabes, \& Spinrad, 2006; Knafo \& Plomin, 2006; Warneken, 2015). Prosocial children, adolescents, and adults are relatively well adjusted and have better social connections than do others low in prosocial behavior (e.g., Clark \& Ladd, 2000; Eisenberg \& Fabes, 1998). Prosocial behavior typically refers to "a large class of voluntary behaviors that share the common intention to benefit another" (Dunfield \& Kuhlmeier, 2013, p. 1766) These behaviors include different activities: helping, comforting, sharing, informing, and cooperating (Hepach, Vaish, \& Tomasello, 2013; Knafo \& Plomin, 2006; Svetlova, Nichols, \& Brownell, 2010).

Theories of social psychology regard helping behavior as one of the most prosocial forms of behavior (e.g., Knafo \& Plomin, 2006; Thompson \& Newton, 2013; Wilhelm \& Bekkers, 2010). Dovidio, Piliavin, Gaertner, Schroeder, and Clark (1991) found that while people associate providing help with positive values, their attitudes toward asking for help are less uniform. There is considerable cultural variation in the evaluation of asking for help: Societies attributing great value to individual will and perseverance are less likely to consider asking for help a positive form of behavior.

In Nagy's (2007) model, both providing help and asking for help are realized in conformance with two fundamental rules (necessity and possibility), that is, both parties must consider whether in the given situation it is necessary and possible to give help or to ask for help. In both cases, the factors affecting the outcome include the environment (such as social expectations, the needs of the other, or the given situation) and other characteristics of the parties in the exchange (such as their values).

Stürmer, Snyder, and Omoto (2004) found distinction between personal and group processes in helping. They demonstrated that "empathy is a stronger factor determining helping a member of the ingroup than a member of the outgroup." Interpersonal factors are stronger predictors of helping for an out-group member than for an ingroup member (Penner, Dovidio, Pilivian, \& Schroeder, 2005).

Cooperation involves two or more people who work or do something together as partners, interdependently,

CONTACT Anikó Zsolnai zsolnai@edpsy.u-szeged.hu Institute of Education, University of Szeged, Social Competence Research Group, H-6722 Szeged, Petőfi Sándor sgt. 30-34, Hungary. 
toward a common goal that will benefit all involved (Penner et al., 2005; Schroeder, Penner, Dovidio, \& Piliavin, 1995). The authors argue that an act of cooperation involves an intention to benefit both the self and the other and both goals are kept in mind at the same time. Trivers (1985) argues that the evolutionary force behind cooperation is the wish to make a contribution to a common goal, where the contribution of each individual is continuously monitored and the distribution of any possible gains depends on this contribution. If a member of the group does nothing or very little to achieve the goal (free riding), they will be evicted from the group. Baron (1997) calls this phenomenon enlightened self-interest: Cooperation furthers the interests of the group, those of others, and those of the self at the same time, which is the main pillar of cooperative behavior. Pruitt (1998) emphasizes the same concept in his dual concern theory: The actor's concern for their own interests and for the interests of others are clearly separated from each other in their goal definitions, contributions, and share of the rewards.

Relying mainly on anthropological (Fiske, 2006) and human ethological (Csányi, 1994) results, Nagy (2007) sees sharing as the goal of cooperation. Based on inner motivation, the most important goal of cooperation is furthering common interests. Contribution and rewards, which are the most important components of cooperation, may be present separately but they lead to more efficient social actions if they are joined together.

If the work of a group is rewarded on an individual basis rather than as a group, there will be negative dependence between the members and a state of conflict, which is accompanied by negative emotions; that is, competition will appear as a behavior that interrupts cooperation and at the same time ends the stability of positive emotions. In addition to mutuality, a general positive attitude, and helping, the cooperative behavior of an individual is also characterized by the appearance of negative emotions, such as anger, if the parties do not adhere to the rules of reciprocity or believe the achievement of the common goal to be in danger, which is similarly rooted in evolutionary processes (Bereczkei, 2008).

Due to the association of helping behavior with positive values, the values of cooperation and helping or supporting others were thought to be closely related for a long time (Fiske, 2006). The results of human ethological studies (e.g., Eibl-Eibesfeldt, 1989), however, suggest that reciprocity functions in different ways in a family environment, among friends, and in other groups, although the reciprocity observed in relationships of the latter category is strongly influenced by the patterns of reciprocity in families and among friends (Stürmer \& Snyder, 2010). The distinction is important from an educational point of view since group work in the classroom does not always involve cooperation between friends.

Rilling et al. (2002) see the greatest difference between cooperation and helping in that while cooperation (shared action) itself can be interpreted as a reward, the size of the reward is more often pondered by the parties of a helping act. These effects appear to decrease as people age, since helping is determined by an increased number of internalized motives, although this mostly holds for helping directed at the members of the actor's environment.

Fiske (2006) contends that danger situations provide the best criterion for defining the difference between cooperation and helping, since the latter but not the former is often triggered by the actor's knowledge that the other is in trouble. In this situation, taking the other persons' interests (what the other wants in the given situation) into consideration has a different effect on action: When in danger, people tend to be less concerned with the other's interests and provide help in accordance with their own interests. Whether helping benefits the other, and whether help is given with the interests of the self or of the other in mind, are both largely determined by the interpretation of a situation, as well as the group norms, social norms, and rules taken into consideration.

It is important to know what age-related changes can be found in prosocial behavior. Early adolescence is a very special period of time when a lot of changes (hormonal, physical, educational, familial) occur. Eisenberg and Fabes (1998) conducted a meta-analysis of age-related changes in prosocial behavior during childhood, early, and late adolescence, and they found that prosocial behavior generally increased with age. But this tendency depends on what kind of aspects of prosocial behavior was compared. For example, age differences were greater for sharing or donating than for comforting or providing instrumental help. These results show that age differences in prosocial behavior are complex (Fabes, Carlo, Kupanoff, \& Laible, 1999). In this research, Eisenberg and Fabes investigated gender differences in prosocial behavior, too, and they found that girls were more prosocial than boys and that difference increased with age. Some new empirical research shows very similar data (e.g., Abdi, 2010).

Several environmental factors, such as family, school, and peers, influence the development of prosocial behavior. In the last decades many studies focused on parental influences on children's prosocial behavior (e.g., Clark \& Ladd, 2000; Eisenberg \& Fabes, 1998; Eisenberg et al., 2006; Knafo et al., 2011). These investigations show that positive parenting style and attitude, warmth toward children, and autonomy support are related to children's prosocial behavior. 


\section{The present study}

Our cross-sectional research looked at the various dimensions (helping, sharing, cooperating) of prosocial behavior among 9-, 11-, and 13-year-olds and specifically focused on the cooperation in school teamwork. In addition to an analysis of age differences, within each age group male and female respondents and student and teacher ratings were also compared, and the relationship between the studied psychic components and parents' education were explored.

Our hypotheses are based on the results of our previous work (Kasik \& Tóth, 2011) and international studies (e.g., Eisenberg \& Fabes, 1998; Eisenberg et al., 2006; Knafo \& Plomin, 2006; Knafo, Israel, \& Ebstein, 2011). We predicted that (a) a significant difference would exist between the three age cohorts in prosocial behavior, (b) the differences between male and female students would involve more dimensions for 11- and 13year-olds than for 9-year-olds in the forms of prosocial behavior, (c) the differences between students' selfratings and teacher ratings should affect more dimensions for 9-year-olds than for the two older cohorts, (d) education would display a stronger association with aspects of the forms of prosocial behavior in the youngest group of children than in the two older groups, and (e) mothers' education would have a stronger explanatory power than fathers' education in all age groups.

There has been a substantial increase in the study of computer-aided data collection in educational and psychological research (e.g., Csapó, Molnár, \& Tóth, 2009; Csapó, Molnár, \& Nagy, 2014). The first efforts have been made to compare paper-based and computerbased versions of psychological tests and questionnaires (e.g., Noyes \& Garland, 2008; Vecchione, Alessendri, \& Barbaranelli, 2012). One of the fundamental questions is whether the paper-based implementation and the computer-based implementation of measurement tools show essentially equivalent reliability indices.

Our previous studies of social competence used exclusively paper-based measurement tools (e.g., Kasik \& Tóth, 2011; Zsolnai, Lesznyák, \& Kasik, 2012), but now for the first time our data were collected online.

\section{Method}

\section{Participants}

One hundred and eighty-five children participated in the survey. Participants were recruited from three elementary schools in Szeged (one of the largest cities in Hungary). The sizes of the subsamples were comparable (9-yearolds $=60 ; 11$-year-olds $=62 ; 13$-year-olds $=63$ ) and there were slightly more girls than boys in each age group (9-year-olds $=54 \% ; \quad 11$-year-olds $=56 \% ; \quad 13$-yearolds $=54 \%)$. All students were native speakers of Hungarian and only those children were eligible whose parents gave their written consent. Parents with all levels of education were involved (mothers: elementary school $=19-21 \%$; vocational school $=22-26 \%$; high school $=24-27 \%$; college degree $=12-15 \%$, university degree $=9-11 \%$; fathers: elementary school $=17-20 \%$; vocational school $=22-26 \%$; high school $=20-24 \%$; college degree $=10-13 \%$, university degree $=7-10 \%$ ). The distribution of these categories is similar in the three age groups (mothers: $\chi^{2}=19.34, p=.49$; fathers: $\left.\chi^{2}=22.31, p=.54\right)$.

For the children, the questionnaires were completed as a whole class. Following previous consultation, every school and class was given a time when the online platform was open and the questionnaires could be completed. The completion of the questionnaires took one class period in all age groups. The children were told that nobody in their school would see their responses.

In addition to the students, 15 teachers (the form teacher of each class) also rated the children's cooperative and prosocial behaviors. In primary schools in Hungary, each class has a designated class teacher. These teachers usually teach major subjects (e.g., mathematics), and they are responsible for all student affairs in their designated class. The teachers completed the questionnaires for each of their students next, also at a pre-agreed time. They had several days to complete the task. They did not have access to the student questionnaires and could not see the students' self-reports. The same explanation was given to the teachers and the students about confidentiality and anonymity.

\section{Instruments}

The cooperation in teamwork was assessed by our own questionnaires: Cooperation Self-Report Questionnaire and Cooperation Teacher-Report Questionnaire, which looks at group cooperation in school situations. The Cooperation Self-Report Questionnaire contains 27 statements, which have to be rated on a 5-point Likert scale $(1=$ not at all characteristic of me, $2=$ slightly characteristic of me, $3=$ somewhat characteristic of me, $4=$ characteristic of me, $5=$ very characteristic of me). In each age group and for both teacher and student raters, the statements group into three factors as revealed by a factor analysis (Kaiser-Meyer-Olkin [KMO] values of over .74 for all age groups and both rater populations): (a) Sharing and rewards (expectation of rewards after shared work, expectations in connection with work and group roles, e.g., Following teamwork, I want to be given rewards in proportion to my work); (b) Norm following 
and exclusion (adhering to and enforcing the rules of cooperative work, exclusion of others, or quitting the group because of inadequate work or wanting unjustified rewards, e.g., If somebody is not working properly, I suggest that they should be excluded from the group); and (c) Contribution and individual and group interests (contribution to completion of shared task, taking the interests of the self and of others into consideration, e.g., When we work on a task in a group, I do a lot of work).

In the self-report version of the questionnaire, the students rate themselves. The teacher-report version is the same as the self-report version except for the modality of the statements (the statements refer to a third-person subject: the children). The measurement tool proved to be reliable for all age groups and for both rater populations with the reliability (Cronbach's alpha) indices being over .82 .

Prosocial behavior was measured using the student and teacher versions of a measurement tool we adapted to our purposes (Prosocial Behavior; Caprara, Barbaranelli, Pastorelli, Bandura, \& Zimbardo, 2000). The original questionnaire contains 15 statements related to the dimension of prosocial behavior, to which 8 more statements were added based on our previous experiences (Kasik, 2009). The 23 statements are rated on a 5-point Likert scale. The factor structure of the questionnaire (cooperation, sharing, goodness, and helping) changed slightly due to the increase in the number of statements. The statements now group into three categories for each age group and rater population (KMO $s$ of over .72 for all age groups and both rater populations): (a) Cooperation and sharing (sharing property with others, lending property to others and a positive attitude towards others, e.g., I let other people use my toys or favorite objects); (b) Helping (giving help to others, e.g., I help my classmates with their homework); and (c) Expression of negative emotions (manifestation of negative emotions, e.g., I get angry when I have to do something I don't like). The measurement tool showed reliability (Cronbach's alpha) values of over .79 for all age groups and both rater populations.

\section{Results}

\section{Cooperation in teamwork and prosocial behavior: Correlations between self-report and teacher-report data}

The results of the correlation analysis of the factors of cooperation and prosocial behavior are summarized in Table 1.

The $z$-tests reveal no significant difference between the correlation coefficients characterizing the relationship between self-reports and teacher reports for Factor II of
Table 1. The correlation $(r)$ between students' and teachers' ratings of prosocial behavior by age group.

\begin{tabular}{lccc}
\hline & \multicolumn{3}{c}{ Age } \\
\cline { 2 - 5 } Behavior and dimension & 9 & 11 & 13 \\
\hline Cooperation & & & \\
I. Sharing and rewards & .43 & .25 & .31 \\
II. Following norms and exclusion & .53 & .45 & .44 \\
III. Contribution and individual and group interests & .33 & .21 & .22 \\
Prosocial & & & \\
I. Expression of negative emotions & .21 & .15 & .18 \\
II. Cooperation and sharing & .35 & .39 & .37 \\
III. Helping & .54 & .31 & .32 \\
\hline
\end{tabular}

Note. Every correlation is statistically significant $(p<.05)$.

cooperation or Factors I and II of prosocial behavior; in these areas, the values are similar for the three age groups (see Table 1). The analysis supports the hypothesis, however, for the factors of Sharing and rewards $\left(z_{9-11}=2.55, p=.02 ; z_{9-13}=3.11, p=.03\right)$, Contribution and individual and group interests $\left(z_{9-11}=4.23\right.$, $\left.p=.02 ; z_{9-13}=3.97, p=.04\right)$, and Helping $\left(z_{9-11}=1.45\right.$, $\left.\mathrm{p}=.01 ; z_{9-13}=2.64, p=.03\right)$, where there is a stronger correlation between teachers' and students' ratings in the 9 -year-old group than in the two older groups, that is, the youngest children's self-ratings are more similar to their teachers' ratings of them than are the older children's.

\section{Cooperation in teamwork and prosocial behavior: Age and gender differences}

The average ratings and standard deviations in the different dimensions and the results of the analysis of variance (ANOVA) are shown in Table 2 for self-reports and Table 3 for teacher reports. Both self-reports and teacher reports indicate that receiving rewards in proportion to work done and expecting role-appropriate work are more typical of 13-year-olds than younger children. The two rater populations also agree that the youngest students are more likely to consider the

Table 2. Students' self-reports of cooperation in teamwork and prosocial behavior (ANOVA).

\begin{tabular}{|c|c|c|c|c|c|c|c|c|}
\hline \multirow[b]{3}{*}{ Behavior and factor } & \multicolumn{6}{|c|}{ Age } & & \\
\hline & \multicolumn{2}{|c|}{9} & \multicolumn{2}{|c|}{11} & \multicolumn{2}{|c|}{13} & \multicolumn{2}{|c|}{ ANOVA } \\
\hline & M & $S D$ & M & $S D$ & M & $S D$ & $F$ & $p$ \\
\hline \multicolumn{9}{|l|}{ Cooperation } \\
\hline I. Sharing and rewards & 2.11 & .92 & 2.21 & .81 & 2.89 & .75 & 13.04 & .02 \\
\hline $\begin{array}{l}\text { II. Following norms } \\
\text { and exclusion }\end{array}$ & 3.67 & .73 & 3.50 & .79 & 3.57 & .71 & 1.59 & .21 \\
\hline $\begin{array}{l}\text { III. Contribution and } \\
\text { individual and group } \\
\text { interests }\end{array}$ & 3.98 & .83 & 3.51 & .88 & 3.44 & .70 & 8.91 & .04 \\
\hline \multicolumn{9}{|l|}{ Prosocial } \\
\hline $\begin{array}{l}\text { I. Expression of negative } \\
\text { emotions }\end{array}$ & 2.56 & .56 & 3.11 & .54 & 3.67 & .78 & 11.02 & .02 \\
\hline $\begin{array}{l}\text { II. Cooperation and } \\
\text { sharing }\end{array}$ & 3.77 & .67 & 3.25 & .55 & 3.13 & .76 & 6.54 & .03 \\
\hline III. Helping & 3.89 & .65 & 3.76 & .74 & 3.21 & .79 & 7.87 & .04 \\
\hline
\end{tabular}


Table 3. Teacher reports of cooperation in teamwork and prosocial behavior (ANOVA).

\begin{tabular}{|c|c|c|c|c|c|c|c|c|}
\hline \multirow[b]{3}{*}{ Behavior and factor } & \multicolumn{6}{|c|}{ Age } & & \\
\hline & \multicolumn{2}{|c|}{9} & \multicolumn{2}{|c|}{11} & \multicolumn{2}{|c|}{13} & \multicolumn{2}{|c|}{ ANOVA } \\
\hline & $M$ & $S D$ & $M$ & $S D$ & $M$ & $S D$ & $F$ & $p$ \\
\hline \multicolumn{9}{|l|}{ Cooperation } \\
\hline I. Sharing and rewards & 2.15 & .67 & 2.53 & .65 & 2.59 & .61 & 11.54 & .01 \\
\hline $\begin{array}{l}\text { II. Following norms } \\
\text { and exclusion }\end{array}$ & 3.25 & .73 & 2.78 & .67 & 2.65 & .59 & 6.44 & .04 \\
\hline $\begin{array}{l}\text { III. Contribution and } \\
\text { individual and group } \\
\text { interests }\end{array}$ & 3.74 & .88 & 3.12 & .67 & 3.10 & .62 & 7.51 & .03 \\
\hline \multicolumn{9}{|l|}{ Prosocial } \\
\hline $\begin{array}{l}\text { I. Expression of negative } \\
\text { emotions }\end{array}$ & 3.13 & .44 & 3.17 & .65 & 3.68 & .78 & 5.41 & .04 \\
\hline $\begin{array}{l}\text { II. Cooperation and } \\
\text { sharing }\end{array}$ & 3.65 & .54 & 3.11 & .55 & 3.20 & .76 & 8.01 & .02 \\
\hline III. Helping & 3.66 & .70 & 3.61 & .49 & 3.12 & .34 & 5.92 & .03 \\
\hline
\end{tabular}

interests of the group during teamwork than are older children, who place greater emphasis on individual interests. Looking at self-reports, the factors of following the norms of team work and excluding others from the group for not working properly or for unjustified expectation of rewards are given similar ratings in the three age groups and there are no statistically significant differences between the ages in this dimension. Looking at teacher reports, however, we find that 13-year-olds are more inclined to exclude others and to violate norms than are younger children.

Both the teachers' and the students' ratings suggest that within prosocial behavior, sharing or lending one's own property and having a positive attitude toward others is more typical of the youngest group than of the two older groups. The raters also agree that helping is more characteristic of the two younger groups than of the oldest group. According to the self-reports, 13-yearolds are the most likely to express negative emotions, 11-year-olds come next in this respect, and 9-year-olds come last; this is the only dimension in which there is a statistically significant difference between the three age groups. The teacher reports find this behavior more characteristic of the oldest students than of the youngest.

The sexes were compared using two-sample $t$-tests in each age group and for both rater populations. The results are displayed in Table 4 (self-reports) and Table 5 (teacher reports).

The results of the self-report questionnaires (Table 4) show a substantial difference between girls and boys for all factors in the 13-year-old age group. For 11-year-olds, significant differences appear in fewer factors (Sharing and rewards; Norm following and exclusion; Expression of negative emotions; and Helping), and even fewer, only two factors, for 9-year-olds (Sharing and rewards; and Helping).

Appropriate sharing, the expectation of role-appropriate work, and helping are more characteristic of girls
Table 4. Gender differences in teamwork cooperation and prosocial behavior in self-reports ( $t$-test).

\begin{tabular}{llll}
\hline & \multicolumn{3}{c}{ Age } \\
\cline { 2 - 4 } Behavior and factor & 9 & \multicolumn{1}{c}{11} & 13 \\
\hline $\begin{array}{l}\text { Cooperation } \\
\text { I. Sharing and rewards }\end{array}$ & $\mathrm{M}<\mathrm{F}$ & $\mathrm{M}<\mathrm{F}$ & $\mathrm{M}<\mathrm{F}$ \\
II. Following norms and exclusion & n.s. & $\mathrm{M}<\mathrm{F}$ & $\mathrm{M}<\mathrm{F}$ \\
$\begin{array}{l}\text { III. Contribution and individual and group } \\
\quad \text { interests }\end{array}$ & n.s. & n.s. & $\mathrm{F}<\mathrm{M}$ \\
$\begin{array}{l}\text { Prosocial } \\
\text { I. Expression of negative emotions }\end{array}$ & n.s. & $\mathrm{M}<\mathrm{F}$ & $\mathrm{M}<\mathrm{F}$ \\
II. Cooperation and sharing & n.s. & n.s. & $\mathrm{F}<\mathrm{M}$ \\
III. Helping & $\mathrm{M}<\mathrm{F}$ & $\mathrm{M}<\mathrm{F}$ & $\mathrm{M}<\mathrm{F}$ \\
\hline
\end{tabular}

Note. F: Female; M: Male; $<$ statistically significant smaller/larger value $(p<0.05)$; n.s. not significant.

than boys in all three age groups. Following norms and excluding others and the expression of negative emotions are more typical of girls than their male peers in the two older groups. The oldest boys are more likely to contribute to teamwork and to cooperate and share than the oldest girls.

Looking at the teachers' reports (Table 5), gender differences are statistically significant for two factors in the youngest age group, and for three factors in each of the two older groups. For the remaining factors the ratings do not show a difference between girls and boys or show the opposite of the students' self-ratings. There is not a single factor where boys show significantly higher values. The teachers believe that following the norms of teamwork and helping are more characteristic of girls in all age groups, which almost matches the results of the self-reports (in the latter, the difference is not statistically significant in the youngest group). The girls in the two older cohorts are more likely to express negative emotions, which also matches the students' ratings of themselves.

\section{Regression analyses}

The interrelationships between the various dimensions of behavior, and the relationships between parents' (mothers' and fathers') education and behavior were analyzed using the self-report data. The six factors were

Table 5. Gender differences in teamwork cooperation and prosocial behavior in teacher-reports ( $t$-test).

\begin{tabular}{llll}
\hline & \multicolumn{3}{c}{ Age } \\
\cline { 2 - 4 } Behavior and factor & \multicolumn{1}{c}{11} & 13 \\
\hline $\begin{array}{l}\text { Cooperation } \\
\text { I. Sharing and rewards }\end{array}$ & n.s. & n.s. & n.s. \\
$\begin{array}{l}\text { II. Following norms and exclusion } \\
\text { III. Contribution and individual and group } \\
\quad \text { interests }\end{array}$ & $\mathrm{M}<\mathrm{F}$ & $\mathrm{M}<\mathrm{F}$ & $\mathrm{M}<\mathrm{F}$ \\
$\begin{array}{l}\text { Prosocial } \\
\text { I. Expression of negative emotions }\end{array}$ & n.s. & n.s. \\
$\begin{array}{l}\text { II. Cooperation and sharing } \\
\text { III. Helping }\end{array}$ & n.s. & $\mathrm{M}<\mathrm{F}$ & $\mathrm{M}<\mathrm{F}$ \\
\hline
\end{tabular}

Note. F: Female; M: Male; $<$ statistically significant smaller/larger value $(p<0.05)$; n.s. not significant. 
Table 6. Results of the regression analysis for 9-year-olds.

\begin{tabular}{lcccccc}
\hline Dependent variable & $C / I$ & $C / I I$ & $C / I I I$ & $P / I$ & $P / I I$ & $P / I I I$ \\
\hline Sharing and rewards (C/I) & & .02 & .07 & .02 & .08 & .04 \\
Following norms and exclusion (C/II) & .06 & & .10 & .05 & .06 & .05 \\
$\begin{array}{l}\text { Contribution and individual and group } \\
\quad \text { interests (C/III) }\end{array}$ & .09 & .04 & & .05 & .05 & .07 \\
Expression of negative emotions (P/I) & .05 & .03 & .07 & & .07 & .07 \\
Cooperation and sharing (P/II) & .04 & .02 & .07 & .04 & & .06 \\
Helping (P/III) & .03 & .01 & .02 & .03 & .05 & \\
Mother's education & .05 & .05 & .04 & .07 & .05 & .04 \\
Father's education & .03 & .02 & .04 & .03 & .02 & .03 \\
Total variance explained $\left(R^{2}\right)$ & .35 & .19 & .39 & .29 & .38 & .37 \\
\hline
\end{tabular}

Note. The values are the products of $B$ (unstandardized estimates) and $\beta$ (standardized estimates).

entered into the regression model as dependent variables and the parents' education as independent variables. The results are shown in Tables 6,7 , and 8 .

The factors of behavior-especially Factors I and IIare correlated with each other (rewards and contribution to teamwork, furthering interests) as was also observed in our previous studies (Zsolnai \& Kasik, 2011), which supports Damasio's (1994) theory. The pattern is not quite as clear for the factors of prosocial behavior, where the correlations are stronger for the 9-year-old cohort (Table 6) than for the older groups (Tables 7 and 8), and this shift is the most obvious for Factors II and III. The expression of negative emotions $(\mathrm{P} / \mathrm{I})$ has a robust explanatory power for all factors and all three ages.

As can be seen in Tables 6, 7, and 8, there is no major difference between the explained variances of the cooperation factors of Sharing and rewards and the prosocial behavior factors of Expression of negative emotions and Helping. The effects of the independent variables are similar in the three age groups in the sample. The explained variances of the cooperation factors of Following norms and exclusion and Contribution and individual and group interests show an increasing trend, while the explained variances of the prosocial factor of Cooperation and sharing show a decreasing trend. Parents' education explains a total of $6-13 \%$ of the variance of each factor in each age group, which is a quarter of the total variances explained.

Table 7. Results of the regression analysis for 11-year-olds.

\begin{tabular}{lcccccc}
\hline Dependent variable & $C / I$ & $C / I I$ & $C / I I I$ & $P / I$ & $P / I I$ & $P / I I I$ \\
\hline Sharing and rewards (C/I) & & .03 & .08 & .03 & .06 & .04 \\
Following norms and exclusion (C/II) & .05 & & .08 & .04 & .06 & .05 \\
$\quad \begin{array}{l}\text { Contribution and individual and group } \\
\quad \text { interests (C/III) }\end{array}$ & .08 & .05 & & .03 & .07 & .03 \\
Expression of negative emotions (P/I) & .04 & .04 & .06 & & & \\
Cooperation and sharing (P/II) & .05 & .03 & .06 & .04 & & .04 \\
Helping (P/III) & .05 & .03 & .06 & .05 & .02 & .05 \\
Mother's education & .04 & .04 & .04 & .04 & .04 & .05 \\
Father's education & .03 & .03 & .04 & .03 & .03 & .05 \\
Total variance explained $\left(R^{2}\right)$ & .31 & .21 & .38 & .21 & .33 & .31 \\
\hline
\end{tabular}

Note. The values are the products of $\mathrm{B}$ (unstandardized estimates) and $\beta$ (standardized estimates).
Table 8 . Results of the regression analysis for 13-year-olds.

\begin{tabular}{lcccccc}
\hline Dependent variable & $C / I$ & $C / I I$ & $C / I I I$ & $P / I$ & $P / I I$ & $P / I I I$ \\
\hline Sharing and rewards (C/I) & & .04 & .07 & .03 & .05 & .03 \\
Following norms and exclusion (C/II) & .04 & & .05 & .03 & .05 & .04 \\
Contribution and individual and group & .06 & .04 & & .04 & .04 & .05 \\
$\quad$ interests (C/III) & & & & & & \\
Expression of negative emotions (P/I) & .05 & .05 & .09 & & .04 & .07 \\
Cooperation and sharing (P/II) & .06 & .04 & .06 & .02 & & .05 \\
Helping (P/III) & .03 & .02 & .10 & .04 & .04 & \\
Mother's education & .05 & .04 & .05 & .06 & .04 & .05 \\
Father's education & .04 & .04 & .04 & .03 & .02 & .03 \\
Total variance explained $\left(R^{2}\right)$ & .33 & .29 & .44 & .25 & .28 & .32 \\
\hline
\end{tabular}

Note. The values are the products of $B$ (unstandardized estimates) and $\beta$ (standardized estimates).

\section{Conclusions}

Our cross-sectional survey used online measurement tools to explore the development of the components of prosocial behavior, and their relationships with a few background variables among 9-, 11-, and 13-year-ld students.

\section{Age and gender differences}

The results suggest that, with the progress of age, selfinterests play an increasingly important role in attitudes toward teamwork (i.e., individual interests become more and more dominant), students attribute increasing importance to rewards proportional to contribution (i.e., the individual rewards matter and should be determined by the amount of work the individual contributed to the achievement of the common goal), and inadequate work or unjustified expectation of rewards is more and more frequently associated with an intention of exclusion or, if given the opportunity, actual exclusion from the group.

As children get older, helping behavior gradually deviates from cooperation and becomes an independent notion, as has also been shown by studies in other countries (e.g., Rilling et al., 2002). The planning and execution of acts of help and the process of helping in the form of sharing are influenced by negative emotions even at a fairly young age. These features of cooperation and prosocial behavior constitute an important consideration in-among other things—organizing teamwork, and they help us to understand the internal dynamics of groups and to make use of them in the classroom.

Both the teachers' and the students' ratings indicate that sharing or lending one's own property and maintaining a positive attitude toward others are more typical of 9-year-olds than the two older age groups. Furthering one's own interests during teamwork is, in contrast, more characteristic of the oldest cohort than the younger ones. Teacher and student raters also agree that helping is more characteristic of the two younger groups than the oldest group. 
Both the students and their teachers consider girls to be more likely than boys to give help in all three age groups in our sample. The two groups of raters agree that the girls in the two older groups express their emotions more than their male peers. In the teachers' reports, none of the factors have significantly higher values for boys, while the self-reports consider the difference to be significant among the 13-year-olds.

\section{Self-report and teacher-report data}

Similarly to other studies (Abdi, 2010; Nourani, 1998; Persson, 2005) our results reveal that teachers' and students' evaluations of a number of dimensions of behavior deviate from each other to a substantial extent. This is especially true for the older students, where the relationship between self-reports and teacher reports is looser than in the case of younger children (Kasik, 2009; Webster-Stratton \& Reid, 2004). Chen (2006) argues that there are several reasons why this pattern is observed in several areas of social behavior. These include time spent together with the students and the structuring of the teaching and learning process (i.e., the particular methods preferred by a teacher and the behaviors that can be observed while using those methods). Although there are differences across countries and education systems, teachers tend to spend more time with younger students (with students in grades 1 to 4 in Hungary) than with older students. Chen (2006) considers that as time passes and teachers spend more time in their teaching careers, their methods and strategies become more stable: They develop schemas and scripts that delineate their teaching behavior and at the same time influence the range of behaviors displayed by the children.

\section{Social background}

The effects of the family are fundamental in the social development of children (e.g., Azad, Blacher, \& Marcoulides, 2014). Especially important factors include the parents' social competence, the attachment relationship with the mother, parenting style, and the relationship with siblings (Cole \& Tan, 2007; Denham et al., 2007; DiPrete \& Jennings, 2011; Schneider, 1993).

Hungarian studies found a significant correlation between social behavior and parents' level of education in preschool children and junior grade students, ${ }^{1}$ and the correlation was found to be the strongest for mothers' education (e.g., Józsa, 2004; Zsolnai \& Józsa, 2003; Zsolnai et al., 2012). These results suggest that educational

\footnotetext{
${ }^{1}$ In Hungary, elementary grades are divided into junior (1st to 4 th) and senior (5th to 8th) grades.
}

attainment is a major factor in parenting style, which in turn has an effect on children's social behavior.

Of the various variables of family background, the current study looked at the effects of parents' education on children's prosocial and cooperative behaviors. The results reveal that the educational attainments of mothers and fathers explain only a small share of the variance in both cooperation and prosocial behavior. The effects are similar for the three age groups. This result does not support the findings of our previous studies. Our previous investigations (e.g., Zsolnai et al., 2012) show that the children of parents with higher educational attainment have better social skills, although this effect disappeared after adolescence (the age of 12). Further studies are needed to find out to what extent children's social development is affected by parents' education.

\section{Study design}

The data collection tools used in our study were all online measurement tools, which allowed faster data collection, data analysis, and feedback. All of the measurement tools proved to be reliable; they can be employed in further research. Letting teachers use these calibrated measurement tools can help us with continuous assessment that is faster to administer than ever before. The results may be useful in rethinking everyday intervention methods and for planning and implementing activities and educational goals. It is worth considering this method for the measurement of other areas of social competence in future studies and comparing the results of paperbased and computer-based methods. Comparative studies carried out in other domains indicate that the two collection methods give similar results (e.g., Józsa, Szenczi, \& Hricsovinyi, 2011; Hülber \& Molnár, 2013).

\section{Limitations and future directions}

Beyond reporting on the results, we consider it is important to call attention to the limitations of our study design. Our study is the first to investigate the various dimensions (helping, sharing, cooperating) of prosocial behavior using online methodology in Hungary. Therefore, current findings cannot be generalized beyond Hungary and it is unclear how these online results relate to data collected by other means. Also, since the sample included children only from a large city, the results may be influenced by the experience of city living. In our future studies, parents' ratings will also be collected. It is well known that parents' opinions about their children's social behavior may differ substantially. Evidence suggests they do not have the same expectations of boys and girls, largely due to traditions of social roles and the roles of the 
parents in the family (e.g., Webster-Stratton, 1988). Beyond these limitations, we are confident that the findings of our study offer useful information about the development of the components of prosocial behavior from middle childhood to early adolescence.

Major considerations in defining a form of behavior and characterizing its properties include its function in social interactions, its structure, its relationship to other forms of behavior, and the psychic components of those forms (e.g., Fiske, 2006; Fülöp, 2008; Nagy, 2007; RoseKrasnor, 1997). Rose-Krasnor argues that starting with these considerations, each form of behavior should be defined and analyzed along various dimensions relating to the subfunctions and psychic components of the behavior and to their interactions. The results of studies adopting this approach can be used to develop bettertargeted intervention programs. Such programs (e.g., Cefai \& Cavioni, 2014; Durlak, Domitrovich, Weissberg, \& Gullotta, 2015) not only contribute to the decrease of conduct problems and to the improvement of students' mental health and social development, but they also increase students' motivation to learn and their academic achievement.

\section{Acknowledgments}

The data collection was carried out in the framework of the project Developing Diagnostic Assessments. Preliminary results of this project have already been published in Hungarian - Zsolnai Anikó és Kasik László (2015): Az együttmüködő viselkedés és az alapérzelem-felismerés online vizsgálata. In: Csapó Benő és Zsolnai Anikó (szerk.): Online diagnosztikus mérések az iskola kezdő szakaszában. Oktatáskutató és Fejlesztő Intézet (OFI), Budapest. 71-95. This is our own work.

\section{About the authors}

Anikó Zsolnai is a Professor of Education at the Institute of Education and the Director of the Social Competence Research Group, University of Szeged, Hungary. Her main research interest is in developing children's social skills and abilities. She has published over 100 manuscripts.

László Kasik is an assistant professor of Institute of Education at the University of Szeged and Social Competence Research Group at University of Szeged in Hungary. His research interests are in educational psychology, development of social competence, and social problem solving.

\section{References}

Abdi, B. (2010). Gender differences in social skills, problem behaviours and academic competence of Iranian Preschool children based on their parent and teacher ratings. ProcediaSocial and Behavioral Sciences, 5, 1175-1179.

Azad, G., Blacher, J., \& Marcoulides, G. (2014). Longitudinal models of socio-economic status: Impact on positive parenting behaviors. International Journal of Behavioural Development, 38(6), 509-517.
Baron, J. (1997). The illusion of morality as self-interest: A reason to cooperate in social dilemmas. Psychological Science, 8, 330-335.

Bereczkei, T. (2008). Evolúciós pszichológia [Evolutionary psychology]. Budapest, Hungary: Osiris Kiadó.

Caprara, G. V., Barbaranelli, C., Pastorelli, C., Bandura, A., \& Zimbardo, P. G. (2000). Prosocial foundations of children's academic achievement. Psychological Science, 11(4), 302-306.

Cefai, C., \& Cavioni, V. (2014). Social and emotional education in primary school. Integrating theory and research into practice. New York, NY: Springer.

Chen, K. (2006). Social skills intervention for students with emotional/behavioral disorders: A literature review from the American perspective. Educational Research and Reviews, 3, $143-149$.

Clark, K. E., \& Ladd, G. W. (2000). Connectedness and autonomy support in parent-child relationships: Links to children's socioemotional orientation and peer relationships. Developmental Psychology, 36, 485-498.

Cole, P. M., \& Tan, P. Z. (2007). Emotion socialization from a cultural perspective. In J. E. Grusec \& P. D. Hastings (Eds.), Handbook of socialization (pp. 516-542). New York, NY: Guilford Press.

Csányi, V. (1994). Viselkedés, gondolkodás, társadalom: Etológiai megközelítés. [Behaviour, cognition, society: and ethological approach]. Budapest, Hungary: Akadémiai Kiadó.

Csapó, B., Molnár, Gy., \& Tóth, R. K. (2009). Comparing paper-and-pencil and online assessment of reasoning skills. A pilot study for introducing electronic testing in large-scale assessment in Hungary. In F. Scheuermann \& J. Björnsson (Eds.), The transition to computer-based assessment. New approaches to skills assessment and implications for large-scale testing (pp. 120-125). Luxembourg, Belgium: Office for Official Publications of the European Communities.

Csapó, B., Molnár, Gy., \& Nagy, J. (2014). Computer-based assessment of school readiness and early reasoning. Journal of Educational Psychology, 106(2), 639-650. doi:10.1037/ a0035756

Damasio, A. R. (1994). Toward a neurobiology of emotion and feeling: Operational concepts and hypotheses. The Neuroscientist, 1, 19-25.

Denham, S. A., Bassett, H. H., \& Wyatt, T. (2007). The socialization of emotional competence. In J. E. Grusec \& P. D. Hastings (Eds.), Handbook of socialization (pp. 614-637). New York, NY: Guilford Press.

DiPrete, T. A., \& Jennings, J. L. (2011). Social and behavioral skills and the gender gap in early educational achievement. Social Science Research, 41(1), 1-15.

Dovidio, J. F., Piliavin, J. A., Gaertner, S., Schroeder, D. A., \& Clark, R. D. (1991). The arousal: Cost-reward model and the process of bystander intervention: A review of the evidence. Measuring prosocial personality 28. In M. S. Clark (Ed.), Prosocial behaviour (pp. 86-118). Newbury Park, CA: Sage.

Dunfield, K. A., \& Kuhlmeier, V. A. (2013). Classifying prosocial behavior: Children's responses to instrumental need, emotional distress, and material desire. Child Development, 84(5), 1766-1776.

Durlak, J. A., Domitrovich, C. E., Weissberg, R. P., \& Gullotta, T. (Eds.). (2015). Handbook of social and emotional learning. New York, NY: Guilford Press.

Eibl-Eibesfeldt, I. (1989). Human etiology. New York, NY: Aldine de Gryter. 
Eisenberg, N., \& Fabes, R. A. (1998). Prosocial development. In N. Eisenberg \& W. Damon (Eds.), Handbook of child psychology: Vol. 4. Social, emotional and personality development (pp. 701-778). New York, NY: Wiley.

Eisenberg, N., Fabes, R. A., \& Spinrad, T. (2006). Prosocial development. In N. Eisenberg (Ed.), Handbook of child psychology: Vol. 3. Social, emotional and personality development (pp. 646-718). Hoboken. NJ: Wiley.

Fabes, R. A., Carlo, G., Kupanoff, K., \& Laible, D. (1999). Early adolescence and prosocial/moral behavior: I. The role of individual processes. Journal of Early Adolescence, 19(1), 5-16. Retrieved from: http://digitalcommons.unl.edu/ psychfacpub/43

Fiske, S. T. (2006). Core motives in social psychology. Budapest, Hungary: Osiris Kiadó.

Fülöp, M. (2008). Paradigmaváltás a versengéskutatásban [Change of paradigms in competition research]. Pszichológia, 28(2), $113-140$.

Hepach, R., Vaish, A., \& Tomasello, M. (2013). A new look at children's prosocial motivation. Infancy, 18(1), 67-90.

Hülber, L., \& Molnár, Gy. (2013). Papír és számítógép alapú tesztelés nagymintás összehasonlító vizsgálata matematika területén, 1-6. évfolyamon [A comparison of pen and paper and computerised testing in mathematics, grades 1-6]. Magyar Pedagógia, 113(4), 243-263.

Józsa, K. (2004). Az első osztályos tanulók elemi alapkészségeinek fejlettsége-Egy longitudinális kutatás első mérési pontja [Developmental level of basic cognitive and social skills in the first grade: Results of a longitudinal study]. Iskolakultúra, 11, 3-16.

Józsa, K., Szenczi, B., \& Hricsovinyi, J. (2011). A tanulási motiváció számítógép-alapú mérési lehetőségei [Computerbased testing of learning motivation]. In B. Csapó \& A. Zsolnai (Eds.), Kognitív és affektív fejlődési folyamatok diagnosztikus értékelésének lehetőségei az iskola kezdö szakaszában (pp. 147-171). Budapest, Hungary: Nemzeti Tankönyvkiadó.

Kasik, L. (2009). A szociálisérdek-érvényesítő, az érzelmi és a szociálisprobléma-megoldó képességek vizsgálata 4-18 évesek körében [A study of social interest realization, emotional, and social problem-solving abilities in children between 4 and 18 years of age] (Doctoral dissertation, University of Szeged, Hungary).

Kasik, L., \& Tóth, E. (2011). Cooperation, competition behaviour of children between 4 and 18 and the effect of parent resources on them. Paper presented at the 14th Biennial Conference for Research on Learning and Instruction (EARLI), "Education for a Global Networked Society," Exeter, UK.

Knafo, A., Israel, S., \& Ebstein, R. (2011). Heritability of children's prosocial behavior and differential susceptibility to parenting by variation in the dopamine receptor D4 gene. Development and Psychopathology, 23, 53-67.

Knafo, A., \& Plomin, R. (2006). Prosocial behavior from early to middle childhood: Genetic and environmental influences on stability and change. Developmental Psychology, 42(5), $771-786$.

Nagy, J. (2007). XXI. század és nevelés [Education in the 21st century]. Budapest, Hungary: Osiris Kiadó.

Nourani, Kh. (1998). Social skills and adaptive behavior of Iranian preschoolers: Teachers' and parents' ratings (Unpublished doctoral thesis). Department of Human Development and Applied Psychology, Ontario Institute for Studies in Education of the University of Toronto.

Noyes, J. M., \& Garland, K. J. (2008). Computer vs. paper-based tasks: Are they equivalent? Ergonomics, 51(9), 1352-1375.

Penner, L. A., Dovidio, J. F., Piliavin, J. A., \& Schroeder, D. A. (2005). Prosocial behavior: Multilevel perspectives. Annual Review of Psychology, 56(14), 1-28.

Persson, G. E. B. (2005). Developmental perspectives on prosocial and aggressive motives in preschoolers'peer interactions. International Journal of Behavioral Development, 29(1), 80-91.

Pruitt, D. G. (1998). Social conflict. In T. D. Gilbert, S. T. Fiske, \& G. Lindzey (Eds.), Handbook of social psychology (pp. 470-503). New York, NY: McGraw-Hill.

Rilling, J. K., Gutman, D. A., Zeh, T. R., Pagnoni, G., Berns, G. S., \& Kilts, C. D. (2002). A neural basis for social cooperation. Neuron, 35, 395-405.

Rose-Krasnor, L. (1997). The nature of social competence: A theoretical review. Social Development, 6, 111-135.

Schneider, B. H. (1993). Children's social competence in context. Oxford, England: Pergamon Press.

Schroeder, D. A., Penner, L., Dovidio, J. F., \& Piliavin, J. A. (1995). The psychology of helping and altruism: Problems and puzzles. New York, NY: McGraw-Hill.

Stürmer, S., Snyder, M., \& Omoto, A. M. (2004). Prosocial emotions and helping: The moderating role of group members. Journal of Personal and Social Psychology, 88(3), 532-546.

Stürmer, S., \& Snyder, M. (2010). The psychology of prosocial behavior. Oxford, England: Wiley-Blackwell.

Svetlova, M., Nichols, S. R., \& Brownell, C. A. (2010). Toddlers' prosocial behavior: From instrumental to empathic to altruistic helping. Child Development, 81, 1814-1827.

Thompson, R. A., \& Newton, E. K. (2013). Baby altruists? Examining the complexity of prosocial motivation in young children. Infancy, 18(1), 120-133.

Trivers, R. L. (1985). Social evolution. Menlo Park, CA: Benjamin/Cummings.

Vecchione, M., Alessandri, G., \& Barbaranelli, C. (2012). Paperand-pencil and web-based testing: The measurement invariance of the Big Five personality tests in applied settings. Assessment, 19(2), 243-246.

Warneken, F. (2015). Precocious prosociality: Why do young children help? Child Development Perspectives, 9, 1-6.

Webster-Stratton, C. (1988). Mothers' and fathers' perceptions of child deviance: Roles of parent and child behaviors and parent adjustment. Journal of Consulting and Clinical Psychology, 56(6), 909-915.

Webster-Stratton, C., \& Reid, J. (2004). Strengthening social and emotional competence in young children: The foundation for early school readiness and success. Infants and Young Children, 2, 96-113.

Wilhelm, M. O., \& Bekkers, R. (2010). Two on morality. Helping behavior, dispositional empathic concern, and the principle of care. Social Psychology Quarterly, 73(1), 11-32.

Zsolnai, A., \& Józsa, K. (2003). Possibilities of criterion referenced social skills development. Journal of Early Childhood Research, 1(2), 181-196.

Zsolnai, A., Lesznyák, M., \& Kasik, L. (2012). Pre-school children's aggressive and pro-social behaviours in stressful situations. Early Child Development and Care, 182(11), $1503-1522$. 